\title{
Breaking Up Is Hard To Do: Media Switching and Media Ideologies
}

When U.S. college students tell breakup stories, they often indicate what medium was used for each exchange. In this article, I explore what this practice reveals about people's media ideologies. By extending previous scholarship on language ideologies to media, I trace how switching media or refusing to switch media contributes to the labor of disconnecting the relationship, determining whether phrases such as "it's over" are effective or not. [breaking up, genre, media ideologies, media switching, new media]

Mary: I had a guy leave me a voice mail at work, so I called him at home. And then he e-mailed me to my Blackberry and so I texted to his cell and then he e-mailed me to my home account, and then the whole thing just got out of control. And I miss the days when you had one phone number and one answering machine. And that one answering machine housed one cassette tape. And that one cassette tape either had a message from the guy or it didn't. And now you just have to go around checking all these different portals just to get rejected by seven different technologies.- monologue spoken by actress Drew Barrymore in the film, He's Just Not That Into You.

Interview with Drew Barrymore:

Cole Haddon: Is there any good way to end a relationship if not in person?

Drew Barrymore: The in-person is first and foremost, a must! Fly. Do whatever you can. The older you get, the more un-okay it is to do it over any technological device. Yes, in person is the starter right there, and then, hopefully, as sweetly and kindly and nurturingly as possible.

http://www.film.com/celebrities/drew-barrymore/story/drew-barrymore-interview-hesjust $/ 25827455$

$\mathrm{H}$ istorians of media have pointed out that, in the U.S., people have repeatedly experienced the "newness" of new media as a source of wonder and anxiety over communicating in newly disembodied ways and with newly contactable people (Gitelman 2006; Marvin 1988; Peters 1999; Sconce 2000). ${ }^{1}$ As these historians have documented, not many contemporary U.S. responses to recently invented media are new responses: not fear that vulnerable people will be manipulated by illintentioned strangers, or fear that people are becoming more isolated or even joy that they are more connected. One of the few contemporary and novel ways in which Americans reflect upon the "newness" of new media occur when they encounter the sheer quantity of communicative technologies now available. This quantity has affected Americans' beliefs, attitudes, and strategies about a single medium (i.e., their media ideology), which is shaped by all the media already present in their media ecologies (for a discussion of contemporary media ecologies, see Fuller 2005; Horst et al. 2009). When Americans discuss how a medium affects a conversation, they implicitly compare that medium to other possible options, and, 
sometimes, decide to reconfigure the interactions by shifting the conversational exchanges to another medium. Contemporary U.S. media ideologies of the "newness" of new media are shaped in part by the possibilities and practicalities of media switching.

This became apparent in my interviews with college students as we discussed how they were using new media to end romantic relationships and friendships. The breakup stories I collected were also narratives about switching media. People of all ages would describe the sequence of events and conversations leading to the breakup, focusing largely on who said what in a reconstructed chronological order. As they did this, my interviewees always pointed out the medium in which each utterance took place. They demarcated any switch in media, letting me know whenever the narrated conversational exchanges switched, for example, from phone to texting. At first, I wondered if my interviewees were humoring me. They knew, after all, that I was interested in how new media were affecting romantic dissolutions. Perhaps they were willing to mark media's presence seamlessly when they narrated their breakup conversations in an interview. When I found the same phenomenon in breakup narratives which people voluntarily posted on websites (e.g., www.e-closure.com; www.dumpedster.com) it became apparent that this is a fairly typical feature of contemporary American breakup narratives.

Many U.S. breakup narratives routinely provide metadiscursive cues linking the utterance with its medium and help to stabilize diffuse conversational exchanges into an overarching type of event-the breakup (see Wortham 2003). The website Dumpedster, for example, encouraged this, suggesting that people classify their breakup stories with the time and method. ${ }^{2}$ Method was uniformly understood by posters to this site as the medium used, which thus implicitly privileges one medium as the breakup medium, and presumably one conversational exchange, while in fact there are many media mentioned in these narratives as integral to the breakup.

\section{WHEN: April 2003 METHOD: by phone message}

A few days into knowing him, he asks me to be his "girlfriend" and I laugh, but accept knowing some disaster was inevitabley impending. Fairly quickly, he pulled what I call "freak show" and he blew me off one weekend. Then his name pops up on my cell and in my pissed off state, I let it go to voicemail. Then I get it (for the first time might I add): The voicemail dumpage. His message is filled with some gems like, "I'm really sorry I didn't call you back." "I'm just so confused and I know I am fucking everything up." "I still want to get coffee and hang out sometime." "Call me back so we can talk about things." And the highlight: "I am not over my ex-girlfriend." To add insult to injury, he moved one block away from me a week later. Then a month later, he tries to add me to his friendster list, so I approve it, even though we are so not friends, and then one day I glance at my friends list only to realize that he removed me! Maybe it's cause I threatened to leave a testimonial about him dumping me on my voicemail. So I guess [I] got dumped on friendster ${ }^{3}$ too. [www.dumpedster.com, accessed on March 5, 2008]

The cell phones, voice mail, Friendster all appear in this narrative. In their stories, people are tracking the media through which breakups are unfolding, detailing how interactions move from one medium to another. Breakups are unstable events-a collection of conversations that might or might not coalesce into a disconnection. In the breakup narratives I collected, organizing conversational interactions into a sequential account of disconnection that would reveal others' intentions also involved marking the media used for each encounter.

Two general features of most U.S. breakup narratives are salient. First, breakup narratives belong to a genre that labels as disconnection a series of ambiguous conversational exchanges in which participants are often uncertain about the end result-disentangling or reconfiguring a relationship. The breakup narrative recontextualizes other conversations and provides both narrator and audience with a metapragmatic frame for these conversations. Second, the narrator often openly engages with the ambiguity at center of these entextualized conversations by ventur- 
ing their own analysis of other people's intentions (see Rosen 1995). What their soon-to-be ex intends is often the central mystery, and central focus, of these stories.

In telling these stories, people are reflecting upon emerging and multiple moral imaginations about what constitutes proper and improper use of new technologies. Many of these narratives revolve around the degree to which particular technologies, or combinations of technologies, allow breaking up to be an effective performative speech act. Breakup conversations are affected by people's views of what is significant about how a medium functions. In other words, people's media ideologies are central to their experiences of media switching during breakups, determining when switching media is a social accomplishment, a transformation in the genre of the conversational interaction, or an unmarked and unnoticed change in technologies.

When talking about breakups, those I interviewed were articulate about how different media affect communication, with varied and nuanced analyses of their daily conversations. It was clear from my interviews that these undergraduates often discussed the ways a medium affected messages with their friends and family, conversational analysis was both widespread and frequent. People were explicit about their media ideologies, which I take to be people's beliefs, attitudes and strategies about the media they use that function in ways parallel to how language ideologies function. Silverstein defines language ideologies as the "set of beliefs about language articulated by users as a rationalization or justification of perceived language structure and use" (1979:193). Similarly, media ideologies, like language ideologies, involve the assumptions that people hold about how a medium accomplishes communicative tasks. In short, media ideologies are what people believe about how the medium affects or should affect the message. And like language ideologies, media ideologies are "multiple, competing and contradictory ... culturally constructed and represent particular political and social interests" (Schiefflin and Doucet 1998:286).

The focus of media ideologies are, for the most part, designed technologies, ${ }^{4}$ and so they are not entirely like language ideologies. Hutchby expands the notion of "affordances" to remind scholars that one can not study media ideologies without also paying attention to the limitations and possibilities embedded in the very structure of a communicative technology. He argues that "technological artifacts both promote certain forms of interaction between participants and constrain the possibilities for other forms of interaction" (Hutchby 2001:32). The structure of a communicative technology, according to Hutchby, is not determinant in itself but contributes to how an interaction will unfold. By turning to the media ideologies underlying media switching, I am stressing people's reflexive understandings of the media they use, while keeping in mind that the affordances of a cell phone are different than the affordances of Facebook (see Boase and Wellman 2006 for a detailed account of different contemporary technologies' affordances). My central concern here, however, is not with the relationship between people's media ideologies and the structure of technology (see Gershon 2010; and Eisenlohr and Kunreuther this volume for such analysis). Rather, I am principally concerned with how people's media ideologies shape their experiences of media switching, focusing on one way that people engage with their changing media ecologies.

Breakup narratives are often an account of a grievance, and as such, could potentially be framed in a number of different ways. In describing the media deployed for an utterance, my interviewees would emphasize how the breakup occurred: the method, not the fact of the breakup or its putative cause, becomes the basis for establishing offense. ${ }^{5}$ Eleanor ${ }^{6}$ volunteered to be interviewed because she felt she had had a particularly unusual breakup that summer. She had been involved her freshman year with someone in her dorm. She wasn't sure whether anything would have happened romantically if they didn't live in the same building. He didn't text, while she was a frequent texter. Most, if not all, of their communication was in person until they both went back home for the summer. They began talking on the phone, but this was not a medium particularly conducive to their relationship. They kept having 
fights over the phone; Eleanor found herself frequently angry at him. She knew a breakup was imminent, but she did not expect the letter on cream stationery, which was written, she suspected, with a fountain pen or something equally old-fashioned. She was outraged that it was so formal- "who does that anymore?" She showed her mother and her friends, who were equally baffled. The right thing to do, the consensus was, would have been to call her on the phone. The choice of cream stationery in a context of so many other possibilities was interpreted as cold, as distancing, as disconcertingly formal. Eleanor's response engaged with the contrast she perceived with his choice between old and new media. She took a stuffed rabbit he had given her as a present and filled it with firecrackers. She filmed the rabbit as it exploded, and then carefully edited the result. When they were back on campus that fall, she showed him the film, telling him: this is how you made me feel when I got the letter. From stationary to stop-motion animation, this disintegrating couple was choosing media that would both cement the breakup and stress their incompatibility. As seems common in many U.S. breakup accounts, much of the social labor of these exchanges was accomplished by focusing on the "how" of the breakup.

\section{Locating Media Switching}

In the ethnographic literature on media, while switching between specific media has been a major focus-especially switching from orality to literacy-media switching in general has not been the focus of much scholarly attention. ${ }^{7}$ Scholars have been far more concerned with the effects of introducing a new channel of communication to a community or culture than the conversational decisions about which medium to use for an exchange. For example, there has been a long-standing interest in the relationship between orality and the written word. Scholars such as Jack Goody and Walter Ong have argued that the introduction of the written word fundamentally transformed how societies remember (Goody 1987; Ong 1982). In these classic accounts, media and culture interpenetrate such that switching from orality to the written word dramatically transforms the epistemological foundations by which cultures constitute themselves. Because these analyses focus on the introduction of a new medium, moving between speech and the written is seen as a far more radical epistemological transition than other moments of media switching, such as when people were choosing between making a phone call or writing a letter on cream stationery.

Other accounts of switching between oral and written modes focus on contexts where the very specificity of two mediums' potential effects, and potential flexibility, are the most significant aspect of the media. Sociolinguists' long-standing interest in the effects and efficacies of different types of transcription are reflexive explorations of media switching, ${ }^{8}$ albeit with a strong focus on media switching as methodology. Mary Bucholtz argues that focusing solely on transcription as a methodology refuses to locate transcription in its larger context. She suggests that transcription also is an engagement with linguistic ideologies that surround how one entextualizes and recontextualizes discourse (Bucholtz 2007:785). Because transcription for sociolinguistics is first and foremost a methodology, scholars often attend to questions of accuracy or variation in the transcription. For these scholars, the act of transcription is a professional necessity; the intention of the transcriber is not an issue. Thus literature on transcription, while also being a literature on media switching, elides precisely what my interviewees were most concerned with when discussing media switching - what the choice of media might reveal about another person's intentions. Narrators of breakups mention media precisely because people's media ideologies presuppose that these media choices will offer insights into the intentions of their interlocutors.

Throughout this article, I occasionally refer to some of the literature on code switching, but in general, while the literature on code switching can be a useful resource for analyzing media switching, it is not invariably so. Code switching is not 
always a close enough analogy to media switching for three reasons. First, code switching often occurs within the same conversational turn, or people can alternate languages between conversational turns, as Gal (1987) points out, in "nonreciprocal" bilingual exchanges. Media switching tends not to occur so rapidly and will separate and demarcate long segments of multiple turn-taking (Murray 1988). Second, people are cognizant when a conversation in one medium becomes a conversation in another medium, unlike code switching, in which it is not always apparent to the speakers when a code "ends" (see Urciuoli 1995). People's language ideologies help determine when code switching is, in fact, taking place. In my fieldwork, media were distinguished clearly enough from each other through their affordances. This was not a labor of division that media ideologies accomplished. Third, as I mentioned earlier, media switching involves switching between different technologies' affordances, and in particular, between how technologies structure participation. The materiality of a medium ensures that media switching is a different act than code switching.

Scholars of new media have theorized the contexts in which media switching takes place, focusing on how beliefs and uses of one medium might affect relations to other media in people's environment (Bolter and Grusin 1999; Fuller 2005; Jenkins 2006; Kittler 1997; McLuhan 1964). While many media theorists have explored this issue broadly through such categories as "media ecologies" (Fuller 2005; McLuhan 1964), "discourse networks" (Kittler 1997) or "convergence culture" (Jenkins 2006), Bolter and Grusin offered an analysis more targeted to addressing the interplay between media in their discussion of remediation. ${ }^{9}$ Bolter and Grusin define remediation as the process by which people's understandings and experiences of one medium are intertwined with those of other media. Every invention enters into a web of media that already have their specific representational abilities defined, and defined vis-à-vis each other. ${ }^{10}$ While older media help shape a new medium's reception and circulation, new media in turn also shape how older media will now be understood. "New digital media are not external agents that come to disrupt an unsuspecting culture. They emerge from within cultural contexts, and they refashion other media, which are embedded in the same or similar contexts" (Bolter and Grusin 1999:17). According to Bolter and Grusin, the interaction between new media and older media is both unstable and dialogic, every medium transforming the others. To understand how people's perceptions of a medium influence their use of that medium, one also has to understand their interactions with all the other media in their environment. This is fundamental to media switching: users are often not only moving from one channel to another, but often also are actively deciding against other possible channels.

In this article, I draw upon 72 interviews, conducted primarily with Indiana University undergraduates between the ages of 18 and 22 during the 2007-2008 and 2008-2009 academic years. Five of my interviews were with people who were older, between the ages of 25 and 50 . I spoke to 54 women and 18 men about their experiences using new media to end relationships and friendships. These people were self-selected; my interviewees responded to requests I made by word of mouth and in large lecture classes, as well as my requests by e-mail to large majors and student organizations on campus. The people I interviewed were raised in the United States, with the exception of one interviewee from the Pacific. The majority of students I interviewed were upper working class to middle class and white. I interviewed six Asian American students, seven African American students and one Latino student. Indiana University is a sizable midwestern state university with approximately 30,000 students enrolled on the Bloomington campus during 2007-2009. Of these 30,000 students, 4,484 of these students are minorities (7.2\%). As a state university, there is a difference in tuition (and thus potentially class background) between in-state students and out-of-state students. This was reflected in my interview sample, the out-of-state students were from more middle-class backgrounds than some of my in-state interviewees. At Indiana University, $56 \%$ of the total number of students have in-state residency (IU Factbook 2007-2008, 2008-2009). 


\section{From Facebook to Texting to Voicemail}

Switching media can be a fraught task, for a number of reasons. First, as Drew Barrymore's character Mary points out, people now frequently have more options of media for almost any utterance than ever before. The people I interviewed mentioned not only texting, but phone calls, e-mail, Skype, voicemail, instant messaging, Facebook messages, Facebook wall posts, Post-It notes, World of Warcraft, and so on. Second, more options has meant more choices between different types of participant structures (see Spitulnik Vidali this volume for a discussion of new media and participant structure). Each technology shapes how communication will take place differently (Hutchby 2001). Voicemail is not conducive for rapid conversational turntaking, while texting not only may be, but also can provide a back channel while other co-present conversations take place. ${ }^{11}$ Some technologies conceal multiple authorship more readily than others-it is easier in practice to have multiple authors of a text message than a voiced phone utterance. Third, each medium has different structures, which will affect differently how public or private the interaction might be. E-mail and text messages can be forwarded much more easily to other people than voicemails. ${ }^{12}$ Fourth, every medium saves its past conversations differently, on instant messaging it is relatively easy to save an entire conversational exchange. The cell phones my interviewees used, by contrast, allow people to store a single texted conversational turn only - every text message was saved individually on their phones. Fifth, different technologies allow for communication in different locations, and with different degrees of labor behind sending a message. E-mailing a message from one's home desktop computer is a different media act than sending an email from one's Blackberry. In short, the structure of a communicative technology affects how an exchange takes place and how it can circulate afterwards.

Yet the structure of the technology by no means determined how the students I interviewed understand what it meant to communicate by that particular medium, and thus what it might indicate when a conversational task (such as breaking up) moved from one medium to another. Not everyone understood how a medium affected a message in the same way. Some saw texting as intimate because one always carried one's cellphone on one's body, it was an ever present form of contact. Others saw it as distancing because every text message has a limit of 160 characters-how much can actually be said in any text? People's media ideologies affected which aspect of the structure of the technology mattered in an exchange.

Just as people's language ideologies are not necessarily accurate about how language functions, the media ideologies I heard did not always accurately reflect how media function. Students often made claims to me about how a feature of Facebook worked, for example, whether the sender of a virtual gift would be known only to the receiver of the gift, or to anyone who could view the profile. These claims were not always correct. Accurate or inaccurate, these beliefs shaped how they used that feature of Facebook. In addition, people may see some media as formal, others as informal, and thus moving between two media changes the formal nature of the exchanges one is having Texting was widely understood to be far more informal than email, students thought that one texted one's friends, but emailed one's professors. Ito and her co-authors found that this was true for U.S. high school students as well, email was not a medium they used to contact their peers (Ito et al. 2009) Thus, for both U.S. high school students and college students, to begin a conversation by text and then switch to email could make the conversation more formal. In short, just as people's metalingual beliefs about how language functions will shape people's language use, so too with their beliefs about media.

\section{Trapped by a Medium}

In my collected breakup narratives, not only switching media is central, refusing to switch media also plays an important role. In these breakup narratives, people are 
detailing not just the switch, but whether the switch occurred in the first place. To switch or not to switch, both can involve social labor. Trill found the reasons why her romantic relationship had just disintegrated deeply confusing. She had started college, and, like many freshmen, found someone she was attracted to in the first semester. It was mutual, and Trill and Todd started making out regularly. At first she thought it was primarily a physical relationship, that all they were doing was messing around (a contemporary U.S. nondating option, see Hamilton and Armstrong 2009). But gradually she began to be interested in him romantically as well. And yet, they never talked in person. They would text each other, but when they were in each other's physical presence and alone, all they did was make out.

Trill: It is easier for me to text, like I don't know, like I don't want to talk to him face-to-face. And I would approach it, I would go "we have to go have dinner or something" and he never would. So I would be like, okay, I'll go back to texting. So it was just easier that way. Like it wasn't the best because you can never tell how like people's emotions are. So it didn't work out very well. That's all I did, I hid behind the text technically.

Ilana: When you say it didn't work out very well, what happened exactly?

Trill: We were more like, we didn't communicate. The only communication was through texting....

Ilana: So you were only texting with him? And then what happened?

Trill: It was like, so our friend, Steve, when we would go to his house, I wouldn't talk to him at all. And then the second I left there, I would text him, and be like "were you okay tonight?" And he would be like "why are you texting me? We were just together for four hours and you didn't say anything to me." And then I texted, and it was like, I don't know, I don't know. He ended up finding somebody else, some other girl, and they talked a lot. I was jealous of that.

Trill couldn't figure out how to switch channels of communication with Todd and also couldn't understand why this proved to be such a stumbling block for her. She would suggest dinners that might allow for co-present exchanges, he would avoid the possibility. She suspected that this was a personal problem for her that "that's all I do is text." Trill and Todd never had a breakup conversation, or exchange of texts to clarify that what was between them was over. It just became obvious that he was seeing someone else. Trill was hurt, but she was also mystified. Why couldn't she switch media?

If this were a case of code switching, instead of media switching, issues of communicative competence would most likely be at the heart of this dilemma. In her study of Puerto Rican bilingual children in New York, Growing up Bilingual, Zentrella suggests that when children resisted moving between English and Spanish it was often because the child felt linguistically inadequate in one language (1997:89). Trill had co-present communication with other people often, a lack of ability was not the reason why Trill did not begin talking in person with Todd. Trill was genuinely puzzled about why she found it so difficult to switch media.

Other college students that I interviewed had had similar experiences or observed friends who felt trapped and frustrated in texting-only relationships. They did believe that this was a feature of youth and associated it with being in high school or being freshmen - that is, older students relegated texting only relationships to a youthful phase people grew out of (see Bucholtz 2002 for a discussion of youth as a constructed category). Those I interviewed offered some hints about the media ideologies that might have led to texting being a medium that seemed to trap young adults. They, like Trill, understood texting to be an informal medium that did not carry intimate or strong emotional undertones. Students often used text messages to initiate flirtatious exchanges because it was so casual, and so difficult to calculate the intensity of intent behind a text message. ${ }^{13}$ Thus, text messages were understood to partially conceal emotional intensity, a useful medium for people uncertain or ambivalent about a particular romantic relationship, or being in a romantic relationship in general. 
This media ideology, that texting could conceal intensity, was a widespread media ideology, present among people in established relationships and/or flirting. When in a relationship in which there was considerable media switching, college students explained that they might choose to text their partner if they were concerned that the utterance spoken might suggest more emotion, such as jealousy, than they wished to convey. Olivia often chose to text statements that have a subtext of inspiring guilt, in part because she could deny the implied guilt trip later.

Olivia: I just feel like it kind of becomes that way because I can always say "well, I didn't meant it that way." It can always be said "that wasn't my tone." And it is so easy that way. Sometimes, you know the next day, if he calls me out on it "why were you being like that, you were being kind of crazy." And sometimes he won't say anything at all. He will take these texts a lot of different ways. ... I know what I want it to sound like, and I know what it could sound like, and I know what my defense will sound like.

Olivia finds that lacking intonation, a text message is underdetermined enough that she is able to make emotional demands that she can subsequently deny. Harmony, who, like Trill, heavily relied on text messages for her communicative needs, explained why she preferred to flirt by text message.

Harmony: It feels more comfortable watching someone doing a math problem than doing it yourself. Like it feels more comfortable letting your cell phone talk for you than doing it yourself. "Okay cellphone, you are going to do this for me." Like you take a friend and "don't tell him, I like him. You do it!" So you are telling your cell phone to tell him so you don't have to do it, basically.

Here Harmony extends the notion of mediation so that the cell phone metaphorically becomes another person. The anxiety around saying certain words is dispelled because the anthropomorphized cell phone performs the act of uttering. The cell phone screen does not, however, magically cleanse a message of its emotional intensity. People infer this cleansing because of their media ideologies.

\section{Media Acts at the Heart of a Breakup}

What social labor do these descriptions of switching media in breakup narratives accomplish for the narrator and the audience? Breakup utterances aren't always effective. There are many performative challenges to making a statement such as "it's over" into a statement that results in a romantic relationship's end. Marking the medium of an utterance provides helpful guidelines for how to interpret the exchanges. In addition, in my interviews, people expressed only partially shared media ideologies. Different social groups can have overlapping but not identical media ideologies. While everyone I spoke to might agree that texting was an informal medium, what that informality meant in practice varied. Some people thought a text message's informality meant that it was unacceptable to send a breakup message by text. Others saw a breakup text as the in-person equivalent of "we have to talk." For them, a text message saying "it's over" might be an opening to a conversation or series of conversations renegotiating the terms of the romantic relationship.

Breakups are often confusing moments, and one is not always certain a breakup is taking place, even if you are the one initiating the breakup. Frank ${ }^{14}$ talked about how he had tried to breakup several times with Maria, but the breakup conversations he initiated never seemed to result in a breakup. He realized that breaking up face-to-face was a social ideal. Indeed, it was such a widely held ideal that of the 72 people I interviewed, only four people did not consider co-present breakups the most appropriate way to end a relationship. ${ }^{15}$ After his experiences breaking up with Maria, Frank became one of the anomalous four. He would try to breakup with Maria in person, and she would become too upset. Finally, he ended the relationship over the phone.

Frank: I was very reluctant to breakup with her in person because I didn't want to be there for her reaction. Because we had broken up once or twice before, and it ended with her 
storming out in tears and I am too compassionate to not let that affect me. I was thinking about all sorts of weird stuff like "What if she never gets to see my dog again? Or my parents? That'll suck." . . I felt that I owed it to her to not do it to her by email or through a Facebook message or whatever, because 18 months. And I didn't really expect it. I knew it had to happen, and we were fighting [on the phone], and that was my chance.

While Frank was trying and failing to create a successful co-present breakup, both he and Maria were enlisting other media to assist them in this tug-of-love. Frank was blogging about his experiences in an open-access blog, and both he and Maria were depicting their relationship as a bit unstable on Facebook through a combination of Facebook's newsfeed and their relationship status. For readers unfamiliar with Facebook's 2007-2008 configuration, on Sept. 5, 2006, Facebook created a newsfeed which announced any change to profiles in one's Facebook network (i.e., one's selected Facebook friends) whenever someone logged onto his or her account. Any alteration to a profile, any photographs added, any public comments exchanged, would be listed for all of one's Facebook friends to see. One person I interviewed in a statement replete with remediation called it "one's personal CNN." The newsfeed kept coming up time and time again in my interviews because Facebook also provided a menu option in which, in 2007-2008, only had six options for a relationship, five of which could be publicly linked to another profile. One could be "single," "in a relationship," "it's complicated," "in an open relationship," "engaged," or "married." In August 2009, Facebook added the option "widowed." Changing the relationship status was an event announced on the newsfeed. There was considerable pressure on the campus to announce and thus make public, one's relationship on Facebook, leading to the common phrase- "It's not official until it's Facebook official" (see Gershon 2010). Frank and Maria had become Facebook official, which presented a problem when Frank began trying to break up. Their status began to switch rapidly between "in a relationship" to "it's complicated" to "single" and then back to "it's complicated" again. ${ }^{16}$

Frank was stuck in a cycle, breaking up was proving much more difficult to accomplish than simply saying the words "it's over." And because of Facebook's newsfeed, he had a broad audience to witness these complications. Finally, tired of this cycle and unable to face Maria's distress in person, Frank broke it off by phone. Frank found that ending the relationship in a less acceptable medium allowed his breakup utterances to be more effective. ${ }^{17}$ The implicit violation in his media switching became necessary to make the breakup conversations lead to a disconnection. People's media ideologies ensure that the medium through which the desire to breakup is uttered contributes to the utterance's effectiveness.

One breakup described to me required only one utterance: this breakup utterance was efficacious in part because of the medium used. Jessica told me she checked her Facebook account one evening and saw in her newsfeed that her boyfriend had announced he was involved with someone else. No phone call, no text message, she found out she was no longer involved with him by checking Facebook. In her interview, she dwelled on the fact that she had logged on to her account relatively late in the day-many other people in both their networks must have known before she did. She didn't contact him after the change in his Facebook relationship status, there was no follow-up conversation exploring each other's reasons or perspectives. He was about to be deployed to Iraq, and Jessica was all too aware that he might not come back. She let the breakup begin and end with the Facebook utterance, and in part, its public declaration of infidelity lay behind her speedy acceptance.

While switching media or the choice of a particular medium contributed to how breakup conversations unfolded, refusing to switch media also could play a significant role. I heard a handful of stories in which one member of the couple refused categorically to switch media. They would respond only in the medium in which they had initiated the breakup, often texting, but with older interviewees, the medium was e-mail. Rebecca told me a story of how her now ex-boyfriend, who went to college in another state, ended a relationship permanently by refusing to switch media. They 
had a rocky relationship, and this was not the first time they had broken up. But they had always managed to work things out in the past. And then, out of the blue, during a period when she thought they were doing well, she got a text message.

Rebecca: I got a text, I was in my class, and it just said "this isn't working out" or something. And I was like "what, what do you mean? I thought things were fine." And then I don't know, he said, I had a girlfriend that I thought I had, and then I lost her." I am like what?

Ilana: He is texting you.

Rebecca: Texting, this is all over text. I hadn't talked to him since a week before we broke up, until four months after we broke up. We didn't speak, it was all text messaging.

Ilana: Why didn't you call him?

Rebecca: I did. He won't answer. He doesn't answer the phone. And I said like "how are you going to do this? We need to talk. You can't just end it like this. This is ridiculous." And he was like "well, I can't talk to you now and whatever. It wouldn't make anything better. You wouldn't change my mind." And so that pissed me off, like "I am not trying to change your mind, I am just trying to understand like what's going on-speaking." It used to be, like, you break up in person-then it was over the phone, now it's text messaging.

Rebecca found this deeply frustrating to have the entire breakup take place by text. Texting she decided, precluded her understanding the breakup, she wanted clarity about his intentions that she saw texting as obscuring. In this and other stories, refusing to switch media ended the relationship for good. Switching media, by contrast, often made it unclear to participants whether the events unfolding were indeed a breakup or instead a moment for imagining the workings of the relationship anew.

\section{The Felicity of Repetition}

Sometimes, even when one person believes a breakup is final, the other person does not accept its finality until it is repeated in another medium. Switching media in these moments functions similarly to Zentella's description of how code switching can sometimes acts as repetition, adding emphasis and clarity. She writes: "What monolinguals accomplish by repeating louder and/or slower, or with a change of wording, bilinguals can accomplish by switching languages. Children learned to use translation for clarification within their turn at speaking, and also tapped into the emphatic power of repetition" (Zentella 1997:96). Switching media can serve the same function in breakup events. In the following narrative, adding emphasis confirms intent. Katie was dating Dirk, who lived in another country. Most of their communication took place over Skype (a free voice and webcam Internet-based medium). She suspected that he was far more in love with her than she was in him. This was in part reinforced by the pragmatics of their Skype conversations-she had a webcam and he did not. Dirk could see her, while all she had access to was his voice. Katie explained: "I felt it was awkward because I couldn't see him, I didn't know what he was doing or how he was reacting. I could tell from his voice but it was awkward because I wasn't comfortable with having him sitting there, watching me. It was almost stalkerish, kind of."

Katie grew more and more uneasy with what she felt was the imbalance in the relationship, and she finally decided to end it. She called Dirk on Skype and told him the relationship was over. As far as she was concerned, it was. She told her friends at work the next day that they had broken up. A week or so later, she decided to change her relationship status on Facebook. Cleansing her Facebook profile of the traces of a relationship had not been a priority for her, it was not part of her postbreakup rituals. ${ }^{18}$

Katie: We broke up that night, and it was really late. It was probably 12:30 or 1 Eastern time and it was 6:30 am for him. It's kind of weird, I was literally lying in bed and waited until it was at least 6 to call him. At that point, for me it was over. And even people at work knew the next day, because some of my friends knew that we were having a lot of problems. I was thinking of breaking up with him, and they knew the next day. I had told them that we broke 
up last night. So for me, that's when it's official, whenever I go and tell that person 'we're breaking up.' We are broken up now. And then we talked on Skype the next day, he wanted to talk about more things and explain stuff more. He wanted me to explain stuff more, and so I did. That was fine. And after that, I thought that was enough explanation. But apparently once I took my status down as being in a relationship with him-I didn't change it to single, I didn't change it to being in a relationship with someone else, I just took it off completely-he sent me a message on Facebook saying: "I guess its official now because you took it off your profile." I actually sent him a message back that said "Wasn't it official whenever we broke up over the phone?"

For Dirk, only repeating the fact of the breakup in a different and more explicitly public medium made the breakup final. Katie was confused by this-for her, the breakup occurred during their Skype breakup conversation. In part, Dirk was responding to the repetition and time lag occurring through this media switch, the breakup utterance through Skype had not sufficed.

This disagreement, accessible to me only through Katie's account, was described as a difference in media ideologies. Katie explained that for Dirk, it wasn't an actual breakup until it was Facebook official. She guessed from his other behavior that he thought private breakups could be renegotiated, ones declared "publicly" through a Facebook relationship status were done deals. ${ }^{19}$ Katie had a different understanding of Facebook, it was both too informal and too public for any significant business of the heart to be accomplished through this medium. In the aftermath of breakups, the disintegrating couple would often describe some of their disagreements as revolving around how best to use a medium or how a medium signals metadiscursive information about a message.

\section{Learning Others' Signals}

Students I interviewed were aware that people used media differently, although they tended to assume a widespread and shared etiquette. In short, while they believed that their media ideologies were much more commonly shared by others than my interviews reflected, they generally understood that there was a lot of diversity in people's media practices. People's different media practices often caused them dilemmas which they would readily discuss. These perceived differences in media practices led Courtney to discuss how much hard work it was to meet new people. Courtney began her explanation by describing when a text message makes her wonder whether her roommate is angry with her.

Courtney: I didn't know if my roommate was mad at me because when she texted me back she only put one " $y$ " with her "hey." And like usually like when we're being friendly we'll be like "heyy" with two "y"s... Y You know what I find is hard is when you meet a new friend. Because you don't know how they text. And I know when I came to school I found that was weird because you'll be talking to someone, and like I said, I know how my roommate texts, and I know when she puts $2 y^{\prime}$ s and when she puts one, and when you meet a new friend you don't know. So then you don't know-you can't read their texting, which is frustrating because with your actual friends you can read it, like you know exactly how they're feeling through it.

For people Courtney knew well by text, small additional texting effort became significant-an extra " $y$ " in "hey" signaled affection. In this instance, Courtney is describing multiple forms of switching along a continuum of informality, switching between lexical items, spelling, as well as channels. Courtney acknowledged these signals were underdetermined and mentioned following up in person or on the phone to ascertain the sender's intended meaning when she suspected there might be tension.

Familiarity with a person's communicative style in one medium did not necessarily entail familiarity with how someone communicates in other media. Those I interviewed found that this could complicate media switching. People weren't only 
navigating others' different media practices, they were also negotiating familiarity with communicative styles across a range of media. Audrey ${ }^{20}$ explained to me that one of her long-distance relationships became a bit strained because they were so used to communicating by instant messaging. They hadn't spent enough time together in person to learn each other's co-present communicative cues well.

Audrey: I got into an argument, I guess we got into a fight and I didn't even know that we got into a fight. I thought we were just arguing. It was over something stupid, like that America is not the number one superpower. I don't know, I don't think America is going to stay the number one superpower, I think we could easily lose that to someone else. He is in the army and I am a little more liberal, and I think that other countries have the vast technology.... He is army and pro-America.

Ilana: When was this? Was this on the phone?

Audrey: This was in person. I wasn't used to it because I thought we were just having a discussion. And he was really mad and he strode off. And I went 'wait, are we in a fight?' And yes, we were. We were in a fight, and I had no idea. You can talk to someone online but you don't get the emotional inflection. Sometimes if you know them really well you can hear them saying those things. And sometimes you get the emotional inflections between the way they write and the speed at which they write it or like the phrasing. Like you can actually pick up the emotional things behind it. ... I didn't know he was fighting with me because we had never had an argument before, at least in person. Yes, online, but typing and physical gestures are two different things.

Audrey was faced with an increasingly common dilemma in having so many channels. Interpretative skills and familiarity developed in one medium did not always transfer smoothly, which contributes to the social labor in media switching. In this instance, she found face-to-face communication with her then boyfriend far more difficult to interpret than instant messaging.

\section{Media Ideologies, Media Practices}

A lack of shared media ideologies complicated already confusing and awkward breakup conversations, since people were often involved with, and thus breaking up with people who held different media ideologies. Yet they tended not to acknowledge that media ideologies were not shared. Contextualizing every utterance in a breakup narrative by marking its medium is thus part of the detective work of determining intent and responsibility. ${ }^{21}$ As an example of how media ideologies were often not shared, as I mentioned earlier, several undergraduates I interviewed suggested that texting breakup was the equivalent of the face-to-face statement "we have to talk." In their experience, a text message suggesting a breakup leads to hours and hours on the phone renegotiating the relationship, after which a breakup may or may not result. Yet, when Halle explained her breakup story which occurred by text, it was clear that Halle did not share the same media ideologies as the students from that class. ${ }^{22}$ She was developing her media ideologies by talking to her mother and friends for whom a text suggesting a breakup was unacceptable.

Ilana: You didn't talk to him after the text message?

Halle: I was livid. Who does that?

Ilana: I don't know who does that.

Halle: He had randomly texted me since, "I miss you."

He would text me "I miss you."

I'd text back "you should have thought of that before."

I have no sympathy for people who pull crap like that.

... I called my mom, and told her about it.

She said, "this is all a big joke, this isn't serious."

I told her "no, this really happened."

She goes "what a schmuck!" 
Phil's text message ended the relationship for Halle, but it did not mean the definitive end of the relationship for Phil. He continued to text her-notice that he continued to contact her through the medium that had so offended her-announcing his abiding romantic interest in her. While Phil may have been relying on the informality of texting to alter the consequences of his declaration of longing for another by text, Halle's media ideology, supported by her mother, speedily ensured this exchange was a breakup exchange, and the definitive one. In this example, the couple's lack of a shared media ideology around texting contributed to the effectiveness of the breakup utterances. Yet Halle in her retelling of the breakup events did not seem to think that Phil might have another media ideology. While she and others understood that media practices differed, those I interviewed tended to presume that everyone shared the same media ideologies and, thus, that there was a widely accepted etiquette surrounding media use in breakups.

\section{Medium Specificity}

In the aftermath of a breakup, media choices could become a way to address the different tasks that disentangling might require. $Q$, a woman in her mid-thirties, described how she and her then wife, Isabella, used e-mail and texting to distinguish emotionally laden conversations from exchanges about the practicalities of divorcing. $Q$ was very upset about Isabella's decision to end the relationship and often reflected on how the breakup was affecting her. As she put it: "Instead of writing down this thought in a journal, I was writing down this thought in a three line e-mail and immediately sending it." Isabella started taking more and more time to respond to her e-mails and also expressed some frustration at receiving these messages. While e-mail became an emotionally charged medium, texting was a medium reserved for low-key exchanges.

Q: We did text. And if I text, she writes back almost immediately. And sometimes I was reading or like giving Jane [a friend] a live play-by-play of the texts that Isabella and I were texting. And she [Jane] said: “It's so weird. I can't believe you guys have this kind of repartee over texting like right now when you are in the middle of trying to come to a financial agreement. The attitudes, or the comments are totally different."

Isabella and $Q$ used the array of different media possibilities to indicate to each other the kind of conversation, and most specifically, the kind of response, required. As e-mail became a medium for $\mathrm{Q}$ to discuss her emotional responses to the divorce, Isabella became more sporadic and slow about responding. The very fact that texting was chosen would indicate the kind of speech event about to take place, and thus received a speedy response. In short, over time, the medium chosen for sending the message came to signal what the message might contain, and how the conversation through that medium might unfold.

In this account, and indeed in all the other breakup narratives I have discussed, media are not interchangeable. ${ }^{23}$ While both texting and e-mail are channels for circulating conversational texts which might be semantically identical, a text message can not substitute seamlessly for an e-mail. By marking each utterance's media, the narrators of breakups are reinforcing this sense that each medium is unique in its effects and function. The breakup narratives' pastiche of media is also simultaneously reinforcing each medium's singularity, implicitly juxtaposing media ideologies that the narrators have developed over time to explain the diversity of other people's uses of relatively new media.

\section{Conclusion}

Contemporary U.S. tellers of breakup narratives mark the media used for the utterances they repeat, in part because the actual utterances have a particular ambiguity at their core-announcing a desire to break up may not result in a breakup. The media 
of the message strongly influence whether or not the utterance will be effective. Most breakup stories I heard involved a range of media as people gradually realized that what was unfolding was a breakup. When people tell stories about the breakups by demarcating what medium accompanied each utterance, they are tracing the detective work they had to do to determine which genre of story this narrative was going to become. The interactions might be a relationship fight leading to renewed commitment, or it might be a breakup. For my interviewees, their soon-to-be ex-lovers' intentions are unclear, can only be retroactively guessed at by seeing how their utterances and actions align. One of the important elements available for interpretation is the medium that people use for their utterance, their choice of media that can be read as formal or informal, enabling intonation or devoid of intonation, allowing for conversational turn-taking or preventing it, public or private, and so on. In narratives, when people track which medium was used and when, they are also addressing how ambiguous the breakup conversations are that they are retelling. These are often scattered interactions that only coalesce into a definitive breakup in hindsight. Breakups, after all, can be performatively difficult to accomplish. As a result, which medium was used when becomes an important part of the shared detective work necessary to understand that a scattered set of conversational exchanges was indeed a breakup narrative.

Examining the media switching in U.S. breakup narratives reveals three other aspects of contemporary U.S. experiences of media switching, remediation, and media ecologies. First, most people I interviewed were sophisticated social analysts of other people's uses of media. Yet while they analyzed the diversity of other people's media practices, they tended to overlook the diversity of other people's beliefs about media. As a consequence, they often claimed that there were widely held beliefs about how a medium affects a message during a breakup, and widely accepted ethical guidelines. Yet, as my interviews revealed, such beliefs are not well established, aside from a general acknowledgment that breakups ideally should be done in person. These beliefs, like language ideologies, were often multiple and contradictory. (see Schieffelin, Woolard and Kroskrity 1998) People often deployed these beliefs strategically, and depending on the circumstances, might claim different media ideologies.

Second, while in some exchanges that are predominately referential, two media can be functionally equivalent - a text message about a school closing is functionally equivalent to an e-mail about a school closing - this is not the case in breakup events. During breakups, media are not functionally interchangeable, and it is the intertwined media ideologies about each medium that can help to determine when saying "it's over" will actually severe. My ethnographic material all revolve around U.S. breakup narratives, but there may be other events in the U.S. and elsewhere when no media is functionally interchangeable as far as the participants are concernedgetting fired or inviting others to a ritual event such as a wedding or a funeral.

Third, I have been careful throughout this article to avoid treating face-to-face communication as the unmarked and nonmediated channel. While ethnographers of speaking have long argued that co-presence is also another medium, this was a claim often reserved for scholarly analysis. No more. A common thread throughout this article is my interviewee's presumption that face-to-face interaction is a medium, often a preferable medium during breakups because it contains the widest bandwidth of information, so to speak. ${ }^{24}$ (See Silvio 2006 for a parallel ethnographic example.) My interviewees discussed the pros and cons of co-present communication in much the same ways they discussed the pros and cons of other media. In short, co-presence is no longer widely evaluated by people on the ground as unmarked and unmediated, instead it is taken to be a medium like any other. In this sense, new media ideologies are affecting ideologies of older media, and even transforming what had not been widely defined as a medium into one.

Those I interviewed were often nostalgic for the times before one had all these technological options. They imagined that dating and breaking up were much easier when, as they saw it, intentions were not so confusing to determine because they were 
not obscured by the sheer range of media practices and technological affordances now available. Historically, fewer communicative options did not make anyone's intentions clearer. But this is part of the ways in which U.S. undergraduates are now experiencing the "newness" of new media, and resenting this newness-they like to believe that before all these options existed, love and heartbreak were more intelligible.

\section{Notes}

Acknowledgments. Conversations with a number of people were influential as I wrote this article: Alexandra Jaffe, Ray McDermott, Bonnie Urciuoli, Richard Bauman, and Susan Gal. I also want to thank Michael Dylan Foster, Javier Leon, Susan Lepselter, Debra Spitulnik Vidali, and Matt Tomlinson for their editorial comments. I am in the debt of my anonymous reviewers, and Miyako Inoue and Paul Manning for encouraging me to reshape this article.

1. This response is cultural, linked to Americans' media ideologies in general. As Don Kulick and Margaret Willson reveal in their account of how nonplussed Gapun villagers in PNG were to watch movies for the first time, ideologies of "newness" need not accompany the introduction of media (1994).

2. Dumpedster.com is no longer a functioning website.

3. Friendster is a social networking site.

4. See my discussion of Akrich (1992) in the introduction of this volume for a fuller account of the significance that media are often designed technologies.

5. My thanks to Ray McDermott for confirming in co-present communication that in his earlier fieldwork Americans focused on the "how" of the breakup in the 1970s as well.

6. Names of interviewees are self-selected pseudonyms.

7. Nardi, Whittaker, and Bradner (2000) are an exception and define media switching much more narrowly than I do, taking media switching to refer only to the moments in one medium in which participants negotiate transferring to another (85). See also Murray (1988) for an application of Hymes' SPEAKING model to the question of media switching in the newly computerized workplace.

8. My thanks to Richard Bauman for pointing out this literature.

9. See Acland (2007) for case studies of remediation. This edited volume explores media ideologies and uses of media that are no longer considered central to most people's daily lives, that is, residual media.

10. This discussion of media's entanglement with other media is similar to Silverstein's discussion of how indexical ordering is always already mutually enregistered (2003).

11. Some students I interviewed told me that while at dinner with many people, they might text sarcastic comments about the voiced conversation to one other co-present person. Ito et al. (2009) and boyd (2008) found that high school students were equally adept at using texting to create back channels.

12. See boyd (2008:230-233) for a discussion of how forwarding affects knowledge circulation among teenagers, and an example of how forwarding led to the dissolution of a friendship.

13. Pascoe (2009:122-123) found this as well in her ethnographic study of how teenagers use new media to fashion intimate relationships, explaining that different stages of flirtation were often relegated to different technologies.

14. A fan of Frank Zappa.

15. Aside from Frank, the other three people who did not find face-to-face breakups the most preferable were women. All three women preferred instant messaging or texting to co-present conversations for breaking up in part because this was more likely to result in an actual breakup.

16. Informal (i.e., it's complicated) and formal (i.e., engaged) characterizations of a relationship are built into Facebook's menu options.

17. While this breakup was effective, it was not permanent. Six months after my interview with Frank, Frank and Maria were back together, and as I type this, they are engaged.

18. See Gershon (2010) for descriptions of people who do use Facebook profiles in postbreakups.

19. See Gershon (2010) for a detailed discussion of changing conceptions of the public/ private dichotomy.

20. A fan of Audrey Hepburn. 
21. And not limited to Internet or cellphone users.

22. I asked her about this point-blank in the interview, but space does not permit me to include this part of the transcript.

23. My thanks to Bonnie Urciuoli for this observation.

24. This analogy between in-person interaction and bandwidth comes from Stone (1996), not my interviewees.

\section{References}

Acland, Charles, ed.

2007 Residual Media. Minneapolis: University of Minnesota Press.

Akrich, Madeline

1992 The De-scription of a Technical Object. In Shaping Technology/Building Society: Studies in Sociotechnical Change. Wiebe E. Bijker and John Law, eds. Pp. 205-224. Cambridge, MA: The MIT Press.

Boase, Jeffrey, and Barry Wellman

2006 Personal Relationships: On and Offline. In The Cambridge Handbook of Personal Relationships. Anita L. Vangelisti and Daniel Perlman, eds. Pp. 709-726. Cambridge: Cambridge University Press.

Bolter, Jay David, and Richard Grusin

1999 Remediation: Understanding New Media. Cambridge, MA: The MIT Press.

boyd, danah

2008 Taken Out of Context: American Teen Sociality in Networked Publics. Ph.D. dissertation, School of Informatics, University of California, Berkeley.

Bucholtz, Mary

2002 Youth and Cultural Practice. Annual Review of Anthropology 31:525-552.

2007 Variation in Transcription. Discourse Studies 9(6):784-808.

dumpedster.com, accessed March 5, 2008.

Fuller, Matthew

2005 Media Ecologies: Materialist Energies in Art and Technology. Cambridge, MA: MIT Press.

Gal, Susan

1987 Codeswitching and Consciousness in the European Periphery. American Ethnologist 14(4):637-653.

Gershon, Ilana

2010 The Breakup 2.0: Disconnecting over New Media. Ithaca: Cornell University Press.

Gitelman, Lisa

2006 Always Already New: Media, History and the Data of Culture. Cambridge, MA: The MIT Press.

Goody, Jack

1987 The Interface between the Written and the Oral. Cambridge: Cambridge University Press.

Hamilton, Laura and Elizabeth Armstrong

2009 Gendered Sexuality in Young Adulthood: Double Binds and Flawed Options. Gender and Society 23(5):589-616.

Horst, Heather, Becky Herr-Stephenson and Laura Robinson

2009 Media Ecologies. In Hanging Out, Messing Around, and Geeking Out: Kids Living and Learning with New Media. Mizuko Ito, et al. eds. Pp. 29-78. Cambridge: The MIT Press.

Hutchby, Ian

2001 Conversation and Technology: From the Telephone to the Internet. Cambridge: Polity Press.

Indiana University

2008/09 Indiana University Factbook. Bloomington, IN: University Reporting and Research. Ito, Mizuko, et al.

2009 Hanging Out, Messing Around, and Geeking Out: Kids Living and Learning with New Media. Cambridge, MA: The MIT Press.

Jenkins, Henry

2006 Convergence Culture: Where Old and New Media Collide. New York: New York University Press.

Kittler, Frederich

1997 Literature, Media, Information Systems. Amsterdam: GB Arts International. 
Kulick, Don and Margaret Willson

1994 Rambo's Wife Saves The Day: Subjugating the Gaze and Subverting the Narrative in a New Guinean Swamp. Visual Anthropology Review 10(2):1-13.

McLuhan, Marshall

1964 Understanding Media: The Extensions of Man. New York: McGraw-Hill.

Marvin, Carolyn

1988 When Old Technologies Were New: Thinking about Electric Communication in the Late Nineteenth Century. New York: Oxford University Press.

Murray, Denise

1988 The Context of Oral and Written Language: A Framework for Mode and Medium Switching. Language in Society 17(3):351-373.

Nardi, Bonnie, Steve Whittaker, and Erin Bradner

2000 Interaction and Outeraction: Instant Messaging in Action. Computer Supported Cooperative Work Conference Proceedings, Philadelphia, PA. Pp. 79-88.

Ong, Walter

1982 Orality and Literacy: The Technologizing of the Word. New York: Methuen.

Pascoe, C. J.

2009 Intimacy. In Hanging Out, Messing Around, and Geeking Out: Kids Living and Learning with New Media. Mizuko Ito, et al. eds. Pp. 117-148. Cambridge, MA: The MIT Press.

Peters, John Durham

1999 Speaking into the Air: A History of the Idea of Communication. Chicago: University of Chicago Press.

Rosen, Lawrence, ed.

1995 Other Intentions: Cultural Contexts and Attribution of Inner States. Santa Fe: School of American Research Press.

Schieffelin, Bambi, Kathryn A. Woolard, and Paul V. Kroskrity, eds.

1998 Language Ideologies: Practice and Theory. New York: Oxford University Press.

Schiefflin, Bambi, and Robin Doucet

1998 The "Real" Haitian Creole: Ideology, Metalinguistics, and Orthographic Choice. In Language Ideologies: Practice and Theory. Edited by Bambi Schieffelin, Kathryn A. Woolard, and Paul V. Kroskrity. Pp. 285-316. New York: Oxford University Press.

Sconce, Jeffrey

2000 Haunted Media: Electronic Presence from Telegraphy to Television. Durham: Duke University Press.

Silverstein, Michael

1979 Language Structure and Linguistic Ideology. In The Elements: A Parasession on Linguistic Units and Levels. R. Cline, W. Hanks, and C. Hofbauer, eds. Pp. 193-247. Chicago: Chicago Linguistic Society.

2003 Indexical Order and the Dialectics of Sociolinguistic Life. Language and Communication 23:193-229.

Silvio, Teri

2006 Informationalized Affect: The Body in Taiwanese Digital Video Puppetry and COSplay. In Embodied Modernities: Corporeality, Representation, and Chinese Cultures. Fran Martin and Larissa Heinrich, eds. Pp. 195-217. Honolulu: University of Hawai'i Press.

Stone, Alluquère Rosanne

1996 The War of Desire and Technology in the Close of the Mechanical Age. Cambridge: MIT Press.

Urciuoli, Bonnie

1995 Languages and Borders. Annual Review of Anthropology 24:525-546.

Wortham, Stanton

2003 Accomplishing Identity in Participant-Denoting Discourse. Journal of Linguistic Anthropology 13(2):189-210.

Zentella, Ana Celia

1997 Growing Up Bilingual: Puerto Rican Children in New York. Malden, MA: Blackwell Publishers.

Department of Communication and Culture

Indiana University

Bloomington, Indiana 47405

igershon@indiana.edu 